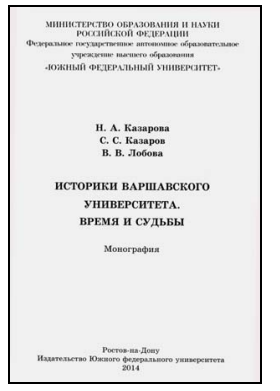

\title{
Artur Kijas
}

(Poznań)

\section{WOKÓŁ KSIĄŻKI UCZONYCH ROSTOWSKICH}

Nina A. Kazarova, Sarkis S. Kazarov, Victoria V. Łobova, Istoriki Varšavskogo Universiteta. Vremja i sud'by, Wydawnictwo Južnogo Federalnogo Universiteta, Rostov-na-Donu 2014, $192 \mathrm{s.}$

W 1869 r., w miejsce zlikwidowanej w Królestwie Polskim Szkoły Głównej Warszawskiej, powstał Cesarski Uniwersytet Warszawski ${ }^{1}$. Podobnie jak inne uniwersytety rosyjskie, składał się z czterech wydziałów: Historyczno-Filologicznego, Prawa, Matematyczno-Fizycznego i Medycznego. Nauczanie w uniwersytecie odbywało się wyłącznie w języku rosyjskim. W gronie profesorów zdecydowanie dominowali Rosjanie. Obok nich w uniwersytecie spotkać można było także Polaków, Żydów, Czechów i przedstawicieli innych narodowości. Studenci rosyjscy stanowili również większość wśród słuchaczy, zwłaszcza na Wydziale Historyczno-Filologicznym. Profesorów Polaków było tam niewielu. Jedynym, który pozostał po strajku $1905 \mathrm{r}$. i wznowieniu zajęć w 1909 r., był Teodor Wierzbowski. Polscy studenci, którzy w drugiej połowie XIX w. decydowali się na studia w Cesarskim Uniwersytecie Warszawskim, najczęściej wybierali wydziały: Prawa i Medyczny.

W opracowaniach polskojęzycznych związanych z dziejami Cesarskiego Uniwersytetu Warszawskiego wydziałom tym poświęcono najwięcej uwagi. Wydział Historyczno-Filologiczny, mimo że pracowało tam wielu wybitnych uczonych rosyjskich, jest stosunkowo słabo rozpoznany. Trzem profesorom związanym z nim - Iwanowi Kozłowskiemu, Grigorijowi Pisariewskiemu i Anatolijowi Semionowowi - poświęcona została monografia „Historycy Uniwersytetu Warszawskiego. Czasy i losy”, której autorami są: Nina i Sarkis Kazarowowie oraz Wiktoria Łobowa, profesorowie Południowego Federalnego Uniwersytetu w Rostowie nad Donem. W książce, oprócz wymienionych historyków przez pewien czas związanych z Warszawą, znalazło się wiele faktów dotyczących Cesarskiego

${ }^{1}$ J. Róziewicz, Polsko-rosyjskie powiązania naukowe (1725-1918), Wrocław-Warszawa-Kraków-Gdańsk-Łódź 1984, s. 280-291. 
Uniwersytetu Warszawskiego, mało znanych badaczom polskim bądź też zupełnie nieznanych. Wystarczy wspomnieć, że w opracowaniu „Dzieje Uniwersytetu Warszawskiego 1807-1915”, wydanym pod redakcją Stefana Kieniewicza, nazwisko żadnego z nich nie figuruje ${ }^{2}$. Nie ma ich też w materiałach bibliograficznych Uniwersytetu Warszawskiego 1870-1915, wydanych na początku XXI w. ${ }^{3}$ Musi to budzić pewne zdziwienie, gdyż $\mathrm{w}$ dorobku profesorów Rosjan Cesarskiego Uniwersytetu Warszawskiego były prace dotyczące dziejów Polski, zarówno okresu staropolskiego, jak i XIX w. Filolog klasyczny Anatolij Semionow należał zaś do wybitniejszych znawców literatury antycznej i wczesnośredniowiecznej. Krótkie biogramy profesorów wymienionych w monografii rostowskich uczonych znaleźć można natomiast w szkicu slawisty uniwersytetu w Briańsku Sergieja Michalczenki, poświęconym Wydziałowi Historyczno-Filologicznemu Uniwersytetu Warszawskiego ${ }^{4}$.

Wydaje się więc, że przypomnienie oryginalnych prac rosyjskich profesorów, a także ich skomplikowanych losów związanych z okresem sowieckim, przez długie lata zapomnianych, może zainteresować czytelnika polskiego, choćby z racji ich związków z Cesarskim Uniwersytetem Warszawskim.

Badaczem dziejów Rosji, głównie XVII w., był Iwan Kozłowski (1869-1942), absolwent Wydziału Historyczno-Filologicznego Uniwersytetu św. Włodzimierza w Kijowie, uczeń znanego historyka kijowskiego Władimira Ikonnikowa. Pod wpływem swego mistrza zainteresował się dawniejszą i nowożytną historią Rosji, źródłoznawstwem, historiografią i archiwistyką. Ikonnikowowi, już jako dojrzały badacz, poświęcił swoją dwutomową pracę „Pierwsze poczty i pierwsi pocztmistrzowie w państwie moskiewskim", doprowadzoną do drugiej połowy XVII w. Monografia w języku rosyjskim wydana została w Warszawie w $1913 \mathrm{r}$. na trzechsetlecie panowania Domu Romanowów.

Po obronie w 1907 r. pracy magisterskiej w Uniwersytecie Charkowskim (w uniwersytetach polskich odpowiednik doktoratu), poświęconej Fiodorowi Rtiszczewowi, Kozłowski zatrudniony został w Uniwersytecie Kijowskim w charakterze privat docenta. W 1909 r., jako nadzwyczajny profesor historii Rosji, otrzymał pracę w Uniwersytecie Warszawskim. Przedmiot ten przed nim wykładali znani badacze: Nikołaj Aristow, Aleksander Nikitski, Nikołaj Barsow, Dymitr Cwietajew, Iwan Filewicz. Studentami Wydziału Historyczno-Filologicz-

\footnotetext{
${ }^{2}$ S. Kieniewicz (red.), Dzieje Uniwersytetu Warszawskiego 1807-1915, Warszawa 1981.

${ }^{3}$ J. Krajewska, A. Bednarz (opr.), Uniwersytet Warszawski 1870-1915. Materiały bibliograficzne, 1-3, Warszawa 2002-2004.

${ }^{4}$ S.I. Michal'čenko, Istoriko-filologičeskij fakul'tet Varšavskogo universiteta 1869-1917 gg. Očerk istorii kafedr, Brjansk 2005, s. 14-15, 16-17, 40-41.
} 
nego, jak wcześniej wspomniano, najczęściej byli Rosjanie. Brak kandydatów powodował, że w pewnych okresach, zwłaszcza w latach rewolucji 1905-1907 roku, zaniechano naboru studentów. Wówczas to kilku profesorów, między innymi Filewicz, opuściło Warszawę. Rekrutację wznowiono w 1908 r. W 1910 r. drugim profesorem $\mathrm{w}$ katedrze historii Rosji został privat docent Uniwersytetu Moskiewskiego Grigorij Pisariewskij.

Oprócz pracy w Uniwersytecie Warszawskim historię Rosji wykładał Kozłowski również w warszawskim gimnazjum Wojciecha Górskiego oraz na Wyższych Żeńskich Kursach Naukowych przy uniwersytecie, uruchomionych na początku XX w.

Wspomniana wcześniej praca dotycząca poczty przyniosła Kozłowskiemu uznanie wśród badaczy dziejów Rosji. Narodziny tej instytucji powiązał autor z niepowodzeniami Rosji w wojnie z Rzeczpospolitą o Ukrainę w XVII w. Zagadnienia natury ogólnej, dotyczące genezy poczty, ukazane zostały przez niego, między innymi, poprzez biografie jej zarządców i naczelników. Kozłowski jako pierwszy z badaczy omówił też szerzej działalność Jana van Svidena, jednego z jej organizatorów. Rezultatem wysiłków Svidena była pierwsza pocztowa linia, która połączyła Moskwę z Rygą, a przez nią z pocztą brandenburską i Europą Zachodnią. Jej operatywność okazała się jednak krótkotrwała. Sporo miejsca w opracowaniu poświęcił również kierownikowi prikazu poselskiego Atanazemu Ordinowowi-Naszczokinowi, reformatorowi rosyjskiej poczty. Inicjatywa Naszczokina doprowadziła do uruchomienia drugiej pocztowej linii do Wilna, zwanej polską. Zgodnie z jego naleganiami punkt dotyczący pocztowych połączeń włączony został do traktatu andruszowskiego z 1667 r., kończącego wojnę polsko-rosyjską. Nowy impuls prowadzący do rozszerzenia pocztowych kontaktów z Europą wiązał ściśle Kozłowski z dyplomatą i naczelnikiem prikazu aptecznego, z pochodzenia Holendrem, Andrzejem Viniusem. Viniusowi poświęcił także odrębną książkę, zatytułowaną „Andrzej Vinius współpracownik Piotra Wielkiego (1641-1717)”, drukowaną w latach 1909-1911 na łamach periodyku „Russkaja Starina" i wydaną jako druk odrębny w $1911 \mathrm{r}$.

Z Cesarskim Uniwersytetem Warszawskim związane były ponadto wykłady monograficzne Kozłowskiego, poświęcone historii rosyjskiej oświaty i metodologii historii. Wybuch pierwszej wojny światowej nieco skomplikował funkcjonowanie Cesarskiego Uniwersytetu Warszawskiego. Już jesienią 1914 r. front niemiecki ustabilizował się na kilkadziesiąt kilometrów od stolicy Królestwa. Rok akademicki 1914-1915 przebiegał jednak bez zakłóceń. Jeszcze w marcu 1915 r. badacz uczestniczył w jubileuszowym posiedzeniu Moskiewskiego Towarzystwa Archeologicznego, a w maju tego roku był delegatem na zjazd profesorów histo- 
rii Rosji i historii prawa w Moskwie w związku z uczczeniem Mikołaja II za zasługi dla nauki historii ojczystej. Na zjeździe podjęto decyzję o skierowaniu do cesarza dziękczynnego adresu i prośby o powołanie okresowych zjazdów profesorów historii rosyjskiej i rosyjskiego prawa, pod nazwą „Nikołajewskich”.

Ofensywa niemiecka podjęta w czerwcu 1915 r. spowodowała, że 23 lipca armia rosyjska opuściła Warszawę. 5 sierpnia 1915 r. miasto zostało zajęte przez wojska niemieckie. Cesarski Uniwersytet został ewakuowany do Rostowa nad Donem. Wraz z innymi profesorami Kozłowski znalazł się w Rostowie, blisko dwustutysięcznym mieście z dominującą populacją Rosjan (stanowili oni tam około 83\% mieszkańców). Pozostał tam jednak niedługo. W lipcu 1916 r. został dyrektorem Instytutu Historyczno-Filologicznego w Nieżynie na Ukrainie, gdzie przebywał do listopada $1918 \mathrm{r}$. Wówczas to do ministerstwa oświaty wysłał prośbę o zwolnienie go $\mathrm{z}$ tego stanowiska ze względu na trudną sytuację. Po jego otrzymaniu powrócił do Rostowa. Ciężkie warunki materialne, brak mieszkania, powodowały jednak, że żyło mu się biednie. Oprócz tego uzależnienie uniwersytetu w Rostowie (nazywanego Uniwersytetem Dońskim) od władzy sowieckiej, co ostatecznie stało się na początku 1920 r., postawiło przed profesorami nowe wymogi. Oznaczało pełne podporządkowanie uczelni bolszewickiej ideologii oraz przyjęcie marksistowskiej metodologii. Jako profesor reprezentujący „starą szkołę akademicką" znalazł się na cenzurowanym. Pragnieniem uczonego było jednak być w dalszym ciągu użytecznym. W uniwersytecie Kozłowski zajął się głównie pracą archiwalną oraz przygotowaniem dla instytucji państwowych przyszłych archiwistów. Z niemałymi trudnościami przepracował do 1930 r., zwolniony w następstwie kolejnej „partyjnej czystki”. Wyrokiem kolegium OGPU z dnia 8 września 1931 r. został zesłany na Ural, skąd przeniósł się do Kazachstanu. W Uralsku, w Instytucie Pedagogicznym, wykładał historię i źródłoznawstwo. Ostatnie prace, które pozostawił w rękopisie, poświęcił rozproszonym materiałom archiwalnym Kazachstanu, które początkowo znajdowały się w Orenburgu, później w Orenburgu i Semipałatyńsku, a od początku lat 30. XX w. w Semipałatyńsku, Pietropawłowsku i Uralsku. Ostatnią pracą uczonego miała być książka „Źródłoznawstwo narodów ZSRR: cykl wykładów wygłoszonych w latach 1909-1940". Mimo zapowiedzi, nie ukazała się ona drukiem. Jej rękopis wysłał do Państwowej Biblioteki Historycznej w Moskwie wraz z dedykacją: „Proszę przyjąć ode mnie w darze moją książkę". Pozbawiony możliwości zamieszkania w europejskiej części Rosji, zmarł w Uralsku 30 listopada 1942 r.

Do wyróżniających się historyków przełomu XIX/XX w. należał Grigorij Pisariewski (1868-1952), który w odróżnieniu od Kozłowskiego, studia, po ukończeniu w 1888 r. Jarosławskiego Seminarium Duchownego, rozpoczął w Cesarskim 
Uniwersytecie Warszawskim. Do profesorów, których wykładów słuchał, należeli Polacy: historyk Adolf Pawiński i filozof Henryk Struve, oraz Rosjanie: Antoni Budiłowicz, Dymitr Cwietajew, Grigorij Zenger, Nikołaj Nowosadski i inni. Po ukończeniu w 1892 r. uniwersytetu podjął pracę w Moskwie w różnych instytucjach pedagogicznych, między innymi w Stroganowowskiej Centralnej Szkole Rysunku Technicznego, a od 1899 r. w Aleksandrowskiej Szkole Handlowej. Należał wówczas do kilku towarzystw naukowych: Wojskowo-Historycznego, Moskiewskiego Archeologicznego, a także Towarzystwa Historii i Starożytności Rosyjskich przy Uniwersytecie Moskiewskim. Do pierwszych, niedużych objętościowo, prac Pisariewskiego należały artykuły dotyczące obcej kolonizacji w Rosji w XVIII w. oraz obecności mennonitów w Rosji. W 1909 r. w uniwersytecie w Kazaniu obronił pracę magisterską zatytułowaną „Z historii cudzoziemskiej kolonizacji w Rosji w XVIII wieku" i jako privat docent w katedrze historii Rosji podjął pracę w Uniwersytecie Moskiewskim. W historiografii rosyjskiej była to pierwsza solidna monografia omawiająca politykę kolonizacyjną w czasach panowania Katarzyny II. Obszerny materiał źródłowy zgromadzony przez Pisariewskiego przyniósł mu znaczne zainteresowanie środowiska historycznego Rosji ${ }^{5}$. Po dziś dzień wielu badaczy zajmujących się problematyką kolonizacji sięga po to opracowanie.

Na początku sierpnia 1910 r. Pisariewski został nadzwyczajnym profesorem w katedrze historii Rosji na Wydziale Historyczno-Filologicznym Cesarskiego Uniwersytetu Warszawskiego. Należy zaznaczyć, że historia Rosji na tym wydziale była przedmiotem obowiązkowym, natomiast na Wydziale Prawa przedmiotem pomocniczym. Stosunkowo krótki okres warszawski przyniósł kilka interesujących przyczynków Pisariewskiego, jak choćby: „Z historii jezuitów w Rosji (kwestia wolności wyznania w koloniach Powołża 100 lat temu wstecz)", „Podróż następcy tronu Konstantego Pawłowicza po Niemczech w 1825 roku przez niego samego opisana". Szczególne miejsce w jego dorobku zajmuje opis życia byłego szwedzkiego króla Gustawa IV Adolfa, który po opuszczeniu Szwecji w 1809 r. zamieszkał w Niemczech pod nazwiskiem pułkownika Gustavsona.

W artykule na temat Konstantego Pawłowicza, zamieszczonym w księdze pamiątkowej dla uczczenia jubileuszu znanego badacza Dymitra Korsakowa, znalazło się kilka interesujących epizodów związanych $\mathrm{z}$ jego bratem carem Aleksandrem I, a także osobami, z którymi wielki książę spotykał się podczas podróży.

${ }^{5}$ Recenzje pracy zamieścili W. Piczeta, D. Cwietajew, P. Szafranow, A. Kizewetter, A. Jakowlew i E. Zagorowskij. 
W czasie pierwszej wojny światowej kontynuacja zajęć w Cesarskim Uniwersytecie Warszawskim stała się niemożliwa. Latem 1915 r. profesorowie z częścią personelu i studentami ewakuowani zostali do Moskwy, a następnie do Rostowa nad Donem. Rok akademicki 1915-1916 w Rostowie rozpoczął się już 1 grudnia 1915 r. Na czterech wydziałach studia podjęło 2205 studentów. Wśród profesorów Wydziału Historyczno-Filologicznego w Rostowie, prócz Pisariewskiego, z uczonych warszawskich znaleźli się: Iwan Kozłowski, Nikołaj Lubowicz, Fiodor Zigel, Leonid Berkut, Aleksander Jewłachow, Jewgienij Bobrow. Z dniem 1 stycznia 1916 roku Pisariewski otrzymał stanowisko profesora zwyczajnego.

W 1916 r. w Rostowie wznowiono również wydawanie „Warszawskich Wiadomości Uniwersyteckich", publikowanych od 1871 r. w cyklu dwumiesięcznym. Już w pierwszym numerze tego periodyku Pisariewski zamieścił obszerny artykuł na temat osiedlenia kolonistów z obszaru Niemiec na terenie Powołża i Noworosji w czasach Katarzyny II. Drugi artykuł drukowany w 1917 r. dotyczył migracji pruskich mennonitów do Rosji w czasach Aleksandra I. Drogę z Prus do Noworosji pokonywali oni przez Gdańsk i Grodno, gdzie dalsze ich przemieszczenie odbywało się pod nadzorem litewskiego gubernatora wojskowego. Przesiedlenia zostały wstrzymane w czasie wielkiej wojny ojczyźnianej 1812 r., lecz po jej zakończeniu - jak to konstatował Pisariewski - były kontynuowane. Nie dotyczył ich ukaz Aleksandra I z 1819 r., zabraniający kolonistom cudzoziemcom osiedlania się w Rosji.

Oprócz kontynuacji badań rozpoczętych jeszcze w Warszawie, w Rostowie wydane zostały wykłady Pisariewskiego zatytułowane „Rosyjska historia XIX wieku” oraz „Historia rosyjska od Katarzyny II do Pawła I włącznie”.

Podobnie jak w wypadku Kozłowskiego, autor opracowania poświęconego Pisariewskimu wiele miejsca poświęca sprawom materialnym profesorów rostowskich. Położenie niektórych $\mathrm{z}$ nich było wręcz tragiczne. Wynagrodzenie $\mathrm{z}$ tytułu pracy $\mathrm{w}$ uniwersytecie nie zabezpieczało podstawowych potrzeb. Warunki mieszkalne odbiegały od tych, jakie mieli w Warszawie. Ponadto opuszczając w pośpiechu to miasto, pozostawili tam dorobek całego swojego życia, meble i książki. Niełatwe życie rostowskich uczonych potwierdza przytoczona wypowiedź kolegi Pisariewskiego, znanego filologa slawisty Aleksandra Jacymirskiego: „O drożyźnie nie chce się pisać, troszczę się o dom i rozdzielam rzeczy na sprzedaż: inaczej nie da się żyć, nawet przy potrójnej pensji”". Pisariewski, wysiedlony z czwartego piętra domu nr 17 przy Zaułku Soborowym, przez pewien czas wraz $\mathrm{z}$ rodziną mieszkał w gabinecie historii rosyjskiej uniwersytetu.

${ }^{6}$ Za: M. Robinson, Losy elity akademickiej. Rosyjska slawistyka od 1917 roku do początku lat 30, Warszawa 2014, s. 117. 
Życie profesorów i wykładowców Uniwersytetu Dońskiego - pisze Sarkis Kazarow - było niełatwe. Ubogie odżywianie, brak mieszkania, nieregularna wypłata niewielkiej pensji (zaledwie 1/6 tego, co profesor otrzymywał wcześniej), prześladowania z powodu światopoglądu i przekonań politycznych powodowały rezygnacje przez wielu przedstawicieli dawnej profesury z pracy dydaktycznej. Ponadto w wyniku wojny domowej mocno ucierpiał majątek uniwersytetu. To, co było cenne, uległo rozgrabieniu. Niejednokrotnie tak wykładowcy, jak studenci podlegali mobilizacji. Większość profesorów w tym czasie była wrogo nastawiona do władzy sowieckiej. Niektórzy z nich w okresie rządów „białych” nad Donem współpracowali z Aleksiejem Kaledinem, Piotrem Krasnowem i Antonem Denikinem, inni później emigrowali za granicę.

Polityka władzy sowieckiej w latach 20. XX w. doprowadziła w konsekwencji do tego, że profesorowie rezygnowali ze swoich stanowisk bądź też w wyniku represji musieli odejść. Po opuszczeniu na początku lutego 1925 roku Rostowa Pisariewski znalazł się w Smoleńsku, gdzie przez rok kierował katedrą historii powszechnej w miejscowym uniwersytecie. W periodyku Uniwersytetu Smoleńskiego opublikował artykuł „Z historii Kongresowego Królestwa Polskiego (1815-1830) w czasach Aleksandra I". W 1926 r. został przeniesiony na katedrę historii narodów ZSRR Uniwersytetu Azerbejdżańskiego w Baku. Tam w 1930 r., $\mathrm{w}$ setną rocznicę powstania listopadowego, wydał pracę „Z historii polskiej rewolucji 1830 roku". Zwalniany i przywracany do pracy, dopiero w 1938 roku mianowany został starszym naukowym pracownikiem w Instytucie Historii azerbejdżańskiego oddziału Akademii Nauk. W dalszym ciągu nieobca mu była problematyka polska. W $1941 \mathrm{r}$. opublikował krótki artykuł „Oblężenie Pskowa przez wojska polsko-litewskie Stefana Batorego w 1581 roku”. Późniejsze drobne prace, $\mathrm{z}$ wyjątkiem wojny ojczyźnianej, kiedy to wydał dwie broszury patriotyczne poświęcone przejściu wojsk rosyjskich przez zamarzniętą Zatokę Botnicką do Szwecji („Lodowa wyprawa armii rosyjskiej w 1809 r.”) i Michaiłowi Kutuzowowi, dotyczyły historii Azerbejdżanu.

Dorobek naukowy Pisariewskiego zasługuje na uwagę nie tylko dlatego, że jako jeden z pierwszych badaczy zajął się kolonizacją i obecnością Niemców na południu Rosji, ale i problematyką polską, która w licznych artykułach i przyczynkach w różnych okresach jego życia znalazła odbicie. Wielka szkoda, że podobnie jak w wypadku Kozłowskiego, jego dorobek uległ zapomnieniu. Zasługuje on na pamięć także dlatego, że, mimo trudności, przeciwności losu oraz cierpień, których nie szczędziło mu życie, nie załamał się, pozostając do końca wiernym etosowi profesora i uczonego. 
Kariera naukowa Anatolija Semionowa (1863-po 1931 r.) była dość nietypowa. Urodził się w stolicy Bawarii - Monachium. W monachijskim gimnazjum otrzymał wszechstronne wykształcenie, zarówno w zakresie języków starożytnych - greki i łaciny, jak i nowożytnych. Studia rozpoczął na Wydziale Medycznym Uniwersytetu Monachijskiego, z którego w 1884 r. przeniósł się na studia filologiczne, poświęcając się filologii klasycznej. W Monachium słuchał wykładów znanych uczonych, znawców antyku, historii Bizancjum i dziejów powszechnych: Wilhelma Christa, Eduarda Wölfflina, Carla Corneliusa, Karla Krumbachera, Rudolfa Schölla. Równolegle do zajęć w uniwersytecie podjął studia $\mathrm{z}$ muzyki w Państwowym Konserwatorium w Monachium. Po zdaniu egzaminu $\mathrm{z}$ teorii muzyki (harmonia, kontrapunkt, fuga) w $1887 \mathrm{r}$. otrzymał dyplom nauczyciela muzyki. W rok później zakończył studia uniwersyteckie z prawem nauczania języków starożytnych w bawarskich gimnazjach. Mimo możliwości, jakie otwierały się przed nim w Bawarii, postanowił wrócić do Moskwy. Zdał egzaminy przewidziane na stopień naukowy magistra i w 1895 r. po obronie dysertacji zatytułowanej „Antiquitates iuris publici Cretorum” otrzymał stopień magistra literatury greckiej. W pracy omówione zostały nie tylko dzieje Krety, które znalazły odbicie w źródłach pisanych, ale i czasy przedhistoryczne związane z Eteokreteńczykami, Kidonami, Kuretami, Korybantami, Telchinami, a także ślady Fenicjan i Egipcjan na obszarze Krety. Semionow sądził, że oligarchia na Krecie pojawiła się około 600 r. p.n.e., a więc około 150 lat po śmierci króla Petearcha.

Pierwszą ważną publikacją przekładową Semionowa było tłumaczenie z języka angielskiego rozprawy Richarda Claverhouse'a Jebba „Homer. Wstęp do Iliady i Odysei”, która ukazała się w Petersburgu w 1892 r. Od 1896 r. Semionow zatrudniony został w Gimnazjum Kijowsko-Peczerskim. Praca nauczyciela związana była $\mathrm{z}$ jego studiami nad twórczością poetów starogreckich oraz analizą greckich rękopisów zawierających żywoty świętych Szymona Słupnika Młodszego (Diwnogorca) i Szymona Teologa. Grecki rękopis Szymona Słupnika Młodszego z XI w. odkrył Semionow, pracując jeszcze w Królewskiej Bibliotece w Monachium. Po powrocie do Rosji postanowił wydać go paralelnie w języku oryginału, to jest greckim, i w przekładzie na język rosyjski. Przebywając w 1898 r. w Wenecji, w tamtejszym archiwum odnalazł rękopis dotyczący Szymona Teologa, również nigdy niepublikowany. Na podstawie przybliżonej daty śmierci Szymona starał się ustalić datę jego urodzin, a także działalność i twórczość, która początkowo związana była z klasztorem studyjskim w Konstantynopolu. Hymny Szymona Teologa traktował jako ważne źródło do studiów nad historią bizantyj- 
skiej sekty hezychastów. W Kijowie również w 1903 r. wydana została monografia Semionowa „Symonides z Keos. Jego życie i poezja”.

W 1903 r. w Kijowskim Okręgu Naukowym Semionow zdał egzaminy pozwalające mu uczyć w gimnazjach języków niemieckiego i francuskiego. Po opuszczeniu w 1906 r. Kijowa, jako nauczyciel języka niemieckiego podjął pracę w jednym z gimnazjów Petersburga. Równocześnie języka greckiego uczył w niemieckiej szkole św. Katarzyny (Katerinischule). Następnie w latach 1907-1910 zatrudniony został $\mathrm{w}$ charakterze privat docenta $\mathrm{w}$ katedrze filologii klasycznej Uniwersytetu Petersburskiego. Przez następne trzy lata, już jako profesor nadzwyczajny literatury greckiej, pracował w Historyczno-Filologicznym Instytucie w Nieżynie. Wydał tam niewielką co do objętości pracę poświęconą procesowi nad słynną z urody heterą grecką Fryne, którą bronił nie mniej znany ateński mówca Hyperejdes. W Nieżynie w dalszym ciągu pracował również nad swym ulubionym greckim autorem Symonidesem. Tymczasem w 1913 r. Wydział Historyczno-Filologiczny Cesarskiego Uniwersytetu w Warszawie wybrał Semionowa na profesora nadzwyczajnego w katedrze literatury greckiej. W czasie pracy w Warszawie opublikował w języku rosyjskim dwa nieduże co do objętości szkice: „O nauce języka greckiego we współczesnych gimnazjach” oraz „Nauczanie i życie szkoły w dawnej Grecji”. W Warszawie mieszkał i wykładał do 1915 r., kiedy to Cesarski Uniwersytet przeniesiony został do Rostowa nad Donem. Tam też w 1916 r. ukazała się jego syntetyczna praca „Zarys historii liryki greckiej okresu klasycznego". Już jako pracownik Uniwersytetu Dońskiego Semionow awansowany został na profesora zwyczajnego. W tym czasie był już na tyle znanym, nie tylko w Rosji, ale i poza nią, uczonym, że w roku akademickim 1918/1919 powierzono mu funkcję dziekana Wydziału Historyczno-Filologicznego.

Wraz z umocnieniem się władzy sowieckiej nad Donem sytuacja Semionowa i jego kolegów - pisze Łobowa - mocno się skomplikowała. Jeśli dotąd tolerowano profesorów „starej szkoły”, gdyż własnych uczonych brakowało, to stopniowo przestano się z nimi liczyć. Stosowano też różne sposoby, aby się z nimi rozstać. Radykalnej zmianie uległ program studiów. W komunistycznym uniwersytecie zabrakło miejsca dla języków starożytnych - greki i łaciny, które były domeną Semionowa. Po drugie, profesura byłego Cesarskiego Uniwersytetu w Warszawie była wówczas $\mathrm{w}$ wieku przedemerytalnym lub emerytalnym i nie było żadnych przeszkód, aby ich wysłać „na zasłużony odpoczynek”. Po trzecie, był to element społecznie obcy, do którego władza sowiecka zaliczała uczonych starej carskiej szkoły. Byli oni prześladowani przez funkcjonariuszy OGPU-NKWD, zsyłani do odległych miejsc oraz stawiani przed sądem. W 1928 r. Semionow, profesor Wydziału Pedagogicznego Uniwersytetu Dońskiego, ze względu na „burżuazyjny 
indywidualizm” i „oderwanie od rzeczywistości” przeniesiony został na emeryturę. Bardzo krótko jeszcze na Wydziale Lekarskim był lektorem języka łacińskiego. W tym niezwykle trudnym dla niego okresie jedynym dobrodziejstwem było przyznanie mu przez Ludowy Komisariat Oświaty stażu w Monachium dla zakończenia dwóch prac rozpoczętych jeszcze przed wybuchem pierwszej wojny światowej: „Historii języka greckiego od Homera do naszych czasów” i „Ewolucji antyczności”. Finalizacja ich w Rostowie nad Donem, z powodu braku literatury, stała się niemożliwa. Wiemy, że rezultaty swoich poszukiwań w bibliotekach Monachium referował na spotkaniach z uczonymi niemieckimi. Wracając do Związku Sowieckiego z Niemiec przez Pragę, odwiedził tam swego ucznia Jana Panasa, dyrektora miejscowego gimnazjum. Wiadomości o życiu Semionowa urywają się nagle na 1931 r. Dalszych faktów na temat jego życia - jak to stwierdza Łobowa - nie udało się ustalić.

Opracowanie uczonych rostowskich, oparte na solidnych materiałach archiwalnych i publikacjach $z$ ostatnich lat, ma duże znaczenie nie tylko dla przypomnienia profesorów, którzy po ewakuacji z Warszawy tworzyli podstawy Uniwersytetu Dońskiego. Z racji ich wcześniejszej pracy w Warszawie ma ono także ogromną wartość dla lepszego poznania funkcjonowania Cesarskiego Uniwersytetu Warszawskiego na przełomie XIX i XX w. Być może, biorąc pod uwagę zawarte w książce polonica, monografię Niny i Sarkisa Kazarowów oraz Wiktorii Łobowej należałoby przetłumaczyć na język polski. 